\title{
Developing Rural Tourism with the Participation of Related Parties in Bac Kan Province
}

\author{
Le Ngoc Nuong ${ }^{*}$, Nguyen Tien Lam ${ }^{*}$, Dinh Tran Ngoc Huy ${ }^{* *}$, \\ Ngo Thi Huyen Trang ${ }^{*}$, Nguyen Thi Thuy Trang ${ }^{*}$
}

\author{
*Thai Nguyen University of Economics and Business Administration, Tan Thinh Ward, Tan Thinh, Thai \\ Nguyen City Vietnam \\ e-mail: ngocnuong85@gmail.com \\ **Banking University HCMC, Ho Chi Minh city Vietnam - International University of Japan, Niigata, \\ Japan
}

DOI: 10.51865/EITC.2021.02.07

\begin{abstract}
Tourism development policy will pay attention to stakeholders, especially to people, who play an important role. However, in reality, when people participate in rural tourism development, they are not equipped with basic knowledge and skills in managing and serving tourists. Because the benefits between stakeholders are still not clear, the participation of people in rural tourism development is currently only passive. Active participation need to be directed from the Government and local authorities because the concept that rural tourism development is not only about creating economic benefits but also associated with conservation and preservation, together with keeping and promoting cultural - historical values in rural areas.
\end{abstract}

Keywords: tourism development; rural tourism, people; Bac Kan.

JEL Classification: M10; M21; Z32.

\section{Introduction}

Rural tourism in Bac Kan has formed for more than a decade and has brought great benefits to participating households. In general, rural tourism in Bac Kan has not really developed to match the potential of a locality with a long origin in agricultural production. Together with the trend of "urbanization" today, this has opened up opportunities to develop diverse forms of tourism in which rural tourism is a relatively new direction.

In rural tourism development, stakeholders, especially people, play an important role. Vietnam Tourism Law 2017 clearly states that residential communities have the right to participate and enjoy legal benefits from tourism activities and are responsible for protecting tourism resources. Accordingly, the residential community has been given the opportunity to invest in tourism development, restore and promote different types of cultures. This shows that the Party and State have highly appreciated activities of developing different types of tourism, including rural tourism. 
However, the reality shows that when people participate in rural tourism development, they are not equipped with basic knowledge and skills in welcoming, managing and serving tourists. In addition, the benefit distribution mechanism among stakeholders is still not really clear. Therefore, the participation of people in rural tourism development is currently only symbolic and passive.

Therefore, the article will focus on researching, analyzing in-depth, understanding the process of people's participation in rural tourism development and through the factors affecting that participation, proposing a number of recommendations and solutions for managers in policymaking to increase their participation in the coming time.

\section{Literature Review}

Pretty (1995) examines different types of community participation in tourism development. Accordingly, there are 5 types of community participation. These include active participation, passive participation, consultation, participation in information provision, participation in the implementation of tourism development functions.

Tosun (2006) studies the barriers in which people participate in tourism development activities. In this study, people will be affected by three groups of barriers when deciding to participate, which are operational barriers, cultural barriers and structural barriers.

Latkova et al (2011) studies the attitudes of people when participating in tourism. This study identifies factors that influence people's participation decisions. Accordingly, there are 3 groups of influencing factors: (1) People's perception of tourism, (2) The role of barriers when participating in tourism, (3) Personal benefits received from tourism.

Nguyen Viet Ha (2012) undertakes research with the aim of understanding the effect of local people's perceptions on willingness to participate in volunteer tourism in Sapa, Lao Cai, Vietnam. The research has built 4 hypotheses and proved that all 4 research hypotheses are accepted through multivariate regression model under the support of SPSS 19.0 software.

Bui Thi Thu Van (2015) performed researches on people's awareness and participation in tourism development. This study used Pearson's correlation to see the relationship between consciousness and people's participation. Accordingly, after conducting the investigation and processing the data, the results obtained is that there is a positive relationship between awareness and participation.

Nguyen Thi My Hanh (2017) conducted research on local community participation in mountainous tourism development, a typical case in Sapa, Lao Cai. Accordingly, the theory of social exchange is used to clearly see the factors affecting people's intention to participate. The results show that the perception of factors affecting both positively and negatively influences people's participation. Besides, the new factor is the added experience when joining tourism. This is a new variable proven to influence the decision to participate in tourism in the future.

Kumar and Sekhar (2020) conclude that the use of technology has developed the way that rural tourism could be conducted. Furthermore, it has opened up ways to use rural tourism as a means to solve existing socio-economic challenges in society. An and Alarcon (2020) confirmed that efforts to understand sustainable rural tourism from the customer perspective have increased since customer loyalty is considered important for sustainability. This study is significant in that, since it evaluated the knowledge status for the first time through systematic review and applied content analysis to academic literature related to sustainability in the sector of rural tourism, it can expand and deepen the knowledge and understanding of related topics and raise awareness of a new research direction. 


\section{Research Methods}

\section{Research sample}

Based on the research object, time and objective of the study, the author conducts a survey at tourist destinations with rural tourism development conditions in Bac Kan province according to the list of suitable sites for development. Rural tourism is based on the research results of "Vietnam rural tourism development practical handbook". Sites that have been researched and proven to have rural tourism activities include: Pac Ngoi village; Coc Toc village; Nam Dai village and Bo Lu village.

For managers: For each village, the author chooses 5 managers, so the number of questionnaires is: $4 * 5=20$ managers.

For residents, the total number of the population in the province that practice rural tourism in Bac Kan as of the end of 2019 is 57 households. Therefore, the author will use the overall survey method to collect information on the participation of households in rural tourism development in Bac Kan province.

Analytical model: The regression model used to analyze the factors affecting the participation of people in rural tourism development has the following form:

$$
\mathrm{Y}=\beta_{0}+\beta_{1} X 1+\beta_{2} \mathrm{X} 2+\beta_{3} X 3+\beta_{4} X 4+\varepsilon_{i}
$$

o Dependent variable (Y): People's participation

o Independent variable $(\mathrm{X})$ includes:

X1: Benefit;

X2: Barriers;

$\mathrm{X} 3$ : People's opinion;

X4: State policy.

\section{Current situation of participation in rural tourism development in Bac Kan province}

The following research results show a relative assessment of the research subjects on the level of people's participation in activities related to rural tourism development. Accordingly, the results were implemented with 57 people and 40 management staff participating in rural tourism development activities in the area.

o Participate in planning process;

Table 1. Situation involved in the planning process 2020

\begin{tabular}{|l|c|c|c|c|}
\hline \multirow{2}{*}{ Content planning } & \multicolumn{2}{c|}{ Resident } & \multicolumn{2}{c|}{ Managers } \\
\cline { 2 - 5 } & Amount & $\begin{array}{c}\text { Ratio } \\
\text { (\%) }\end{array}$ & Amount & $\begin{array}{c}\text { Ratio } \\
\text { (\%) }\end{array}$ \\
\hline $\begin{array}{l}\text { Participate in collecting resource data on rural } \\
\text { tourism }\end{array}$ & $43 / 57$ & 75.4 & $25 / 40$ & 62.5 \\
\hline $\begin{array}{l}\text { Participate in proposing rural tourism } \\
\text { development ideas }\end{array}$ & $49 / 57$ & 86 & $31 / 40$ & 77.5 \\
\hline $\begin{array}{l}\text { Participate in setting rural tourism development } \\
\text { goals and targets }\end{array}$ & $48 / 57$ & 84.2 & $31 / 40$ & 77.5 \\
\hline Participate in building an implementation plan & $46 / 57$ & 80.7 & $31 / 40$ & 77.5 \\
\hline
\end{tabular}

Source: Results of survey data analysis, 2020.

The analyzed results in Table 1 show that there is a difference in the assessment between the different surveyed subjects. If people show a high level of agreement on the contents of the 
planning process in which they participate, the management staff, particularly the village leaders and the socio-cultural staff of Communes showed lower levels of consent. Accordingly, from the point of view of local residents, they assessed that they have the highest participation in the concept of rural tourism development in the area and that they have participated in data collection. Rural tourism is considered to be the lowest level by people. Meanwhile, from the point on view of managers, they appreciate the role of people in participating in the stages of proposing rural tourism development ideas. So they set rural tourism development goals and targets and develop implementation plans, although the level of consent is generally not as high as that of the people as analyzed above.

o Participate in the process of building an organizational structure;

Table 2. Content involved in the process of building an organizational structure 2020

\begin{tabular}{|l|c|c|c|c|}
\hline \multirow{2}{*}{ Content building organizational structure } & Amount & $\begin{array}{c}\text { Ratio } \\
\text { (\%) }\end{array}$ & Amount & $\begin{array}{c}\text { Ratio } \\
\text { (\%) }\end{array}$ \\
\cline { 2 - 5 } & $23 / 57$ & 40.4 & $13 / 40$ & 32.5 \\
\hline $\begin{array}{l}\text { Participate in human resource proposal to } \\
\text { manage rural tourism development }\end{array}$ & $21 / 57$ & 36.8 & $12 / 40$ & 30 \\
\hline $\begin{array}{l}\text { Participate in building operational regulations of } \\
\text { the organization }\end{array}$ & $26 / 57$ & 45.6 & $15 / 40$ & 37.5 \\
\hline $\begin{array}{l}\text { Participate in the management staff in the } \\
\text { decision-making process of rural tourism } \\
\text { development }\end{array}$ & & & \\
\hline
\end{tabular}

Source: Results of survey data analysis, 2020.

With content participating in the process of building the organizational structure, the research results show that the level of consent on the participation content of the people is not high when the opinions are not yet $50 \%$ of the respondents' agreement. Accordingly, both the management staff and the people have low assessment of the organization's process of setting up operating regulations. This can be explained by the reason that the people's education level is not high, leading to people not taking part into important jobs that require thinking and involving.

0 Participate in the design process of tourism products and services;

Table 3. Content involved in the design process of tourism products and services 2020

\begin{tabular}{|l|c|c|c|c|}
\hline \multirow{2}{*}{ Product design content travel services } & \multicolumn{2}{|c|}{ Resident } & \multicolumn{2}{c|}{ Managers } \\
\cline { 2 - 5 } & Amount & $\begin{array}{c}\text { Ratio } \\
\text { (\%) }\end{array}$ & Amount & $\begin{array}{c}\text { Ratio } \\
\text { (\%) }\end{array}$ \\
\hline $\begin{array}{l}\text { Visiting and learning the model of rural } \\
\text { tourism development in localities at home } \\
\text { and abroad }\end{array}$ & $27 / 57$ & 47.4 & $21 / 40$ & 52.5 \\
\hline $\begin{array}{l}\text { Participate in proposing ideas for building } \\
\text { specific rural tourism products of the locality }\end{array}$ & $42 / 57$ & 73.7 & $25 / 40$ & 62.5 \\
\hline
\end{tabular}

Source: Results of survey data analysis, 2020.

The design process of rural tourism products is shown through the contents in Table 3 . The content of visiting and learning the model of rural tourism development in localities at home and abroad has been appreciated by neither the people nor the management staff because of the real development of different types of tourism. In general, and rural tourism in particular in the research areas of Bac Kan province have not been highly appreciated by the local authorities and policy makers and the funding for this activity has not been widely allocated.

o Participate in the process of receiving visitors; 
Table 4. Content participates in the process of receiving visitors 2020

\begin{tabular}{|l|c|c|c|c|}
\hline \multirow{2}{*}{ Content receiving visitors } & \multicolumn{2}{c|}{ Resident } & \multicolumn{2}{c|}{ Managers } \\
\cline { 2 - 5 } & Amount & $\begin{array}{c}\text { Ratio } \\
\text { (\%) }\end{array}$ & Amount & $\begin{array}{c}\text { Ratio } \\
\text { (\%) }\end{array}$ \\
\hline $\begin{array}{l}\text { Develop regulatory regulations on rural access } \\
\text { for tourists }\end{array}$ & $38 / 57$ & 66.7 & $23 / 40$ & 57.5 \\
\hline $\begin{array}{l}\text { Provide information about tours and } \\
\text { attractions for tourists }\end{array}$ & $48 / 57$ & 84.2 & $25 / 40$ & 62.5 \\
\hline Designing tourism products specific to regions & $41 / 57$ & 71.9 & $24 / 40$ & 60 \\
\hline $\begin{array}{l}\text { Create a safe and hygienic accommodation } \\
\text { environment to serve tourists }\end{array}$ & $39 / 57$ & 68.4 & $24 / 40$ & 60 \\
\hline
\end{tabular}

Source: Results of survey data analysis, 2020.

Among the contents in which people participate in rural tourism development, the visitor welcoming process is directly related and associated with the relationships between other stakeholders in the local community. This means that the best possible reception of tourists requires a close coordination between the parties, namely local authorities, tourism service providers, industry agencies and people - subjects standing at a central role in the connection. Because of that importance, both the people and the management staff appreciate and show a high agreement with this content. In particular, the stage of providing information about tours, tourist destinations for tourists and designing tourism products specific to regions was rated highest by both participants. In addition, there is more expectation on the participation of people in creating a safe and hygienic accommodation environment to serve tourists.

o Participate in tourism promotion;

Table 5. Content participating in the promotion of tourism 2020

\begin{tabular}{|l|c|c|c|c|}
\hline \multirow{2}{*}{ Content promotion of tourism } & \multicolumn{2}{|c|}{ Resident } & \multicolumn{2}{c|}{ Managers } \\
\cline { 2 - 5 } & Amount & $\begin{array}{c}\text { Ratio } \\
\text { (\%) }\end{array}$ & Amount & $\begin{array}{c}\text { Ratio } \\
\text { (\%) }\end{array}$ \\
\hline $\begin{array}{l}\text { Participate in the promotion of rural tourism } \\
\text { services through rural tourism products and } \\
\text { services }\end{array}$ & $28 / 57$ & 49.1 & $19 / 40$ & 47.5 \\
\hline $\begin{array}{l}\text { Participate in promoting rural tourism services } \\
\text { through the media (Internet, newspaper, radio, } \\
\ldots)\end{array}$ & $20 / 57$ & 35.1 & $13 / 40$ & 32.5 \\
\hline $\begin{array}{l}\text { Participate in promotion through service } \\
\text { quality based on visitor feedback }\end{array}$ & $26 / 57$ & 45.6 & $17 / 40$ & 42.5 \\
\hline
\end{tabular}

Source: Results of survey data analysis, 2020.

The study shows that the promotion of rural tourism, although appreciated by people and government officials, is not really looked favorably upon. Mainly, people only participate in promoting rural tourism services through rural tourism products and services associated with famous regional specialties such as Tay people, or from well-known rural areas. The modern and more active activities such as promoting rural tourism services through the media (Internet, newspapers, radio, ...) are not really appreciated by people and authorities.

o Participate in tourism control and management;

Table 6. Content involved in the control and management of tourism 2020

\begin{tabular}{|l|c|c|c|c|}
\hline \multirow{2}{*}{ Content control and travel management } & \multicolumn{2}{|c|}{ Resident } & \multicolumn{2}{|c|}{ Managers } \\
\cline { 2 - 5 } & Amount & $\begin{array}{c}\text { Ratio } \\
\text { (\%) }\end{array}$ & Amount & $\begin{array}{c}\text { Ratio } \\
\text { (\%) }\end{array}$ \\
\hline $\begin{array}{l}\text { Gather information on the number of } \\
\text { tourists, local tourism revenue }\end{array}$ & $20 / 57$ & 35.1 & $12 / 40$ & 30 \\
\hline
\end{tabular}




\begin{tabular}{|l|c|c|c|c|}
\hline $\begin{array}{l}\text { Compare and analyze the rural tourism } \\
\text { development indicators and the actual results } \\
\text { achieved locally }\end{array}$ & $21 / 57$ & 36.8 & $13 / 40$ & 32.5 \\
\hline $\begin{array}{l}\text { Proposing solutions to attract local visitors } \\
\text { in the future }\end{array}$ & $23 / 57$ & 40.4 & $15 / 40$ & 37.5 \\
\hline
\end{tabular}

Source: Results of survey data analysis, 2020.

Activities covered here including organizational structure building, tourism promotion, as well as tourism control \& management have been tapped into by local people, but the level of interest and appreciation are not high for both residents and managers. Table 6 shows that only the content proposing solutions to attract local visitors in the future is of much interest to the people and officials. However, the remaining issues addressing developing strategies to control and manage rural tourism in the future have not been mentioned. A stable and sustainable development of this type of tourism can help reduce poverty, improve income and living standards of the local; however, a long-term strategy is difficult to formulate.

In addition, the results also show a comparison of the level of participation in rural tourism development among research subjects. Accordingly, the assessment of people about their own participation is higher than that of managers. This indicates that there is a difference in the perception and assessment between the two subjects by education level, subjective perspective as well as opinions in general.

\section{Level of participation in rural tourism development process}

The participation level is shown under two aspects: passive participation and active participation. The first two levels in the table are defined by the author as passive participation whereas the remaining four levels are generalized as active participation. Accordingly, the contents of planning, designing tourism products, services and receiving visitors are aspects in which people actively take part in. However, in terms of building the organizational structure, promotion and control \& management, the local people have passively merge themselves into the process and only do such things under the steering of the authorities and receive announcement from the authorities once the work has been completed.

Table 7. Level of participation in rural tourism development in Bac Kan province 2020

Unit: \%

\begin{tabular}{|l|c|c|c|c|c|c|}
\hline \multicolumn{1}{|c|}{ Level } & Planning & $\begin{array}{c}\text { Building an } \\
\text { organizational } \\
\text { structure }\end{array}$ & $\begin{array}{c}\text { Designing } \\
\text { tourism } \\
\text { products } \\
\text { and } \\
\text { services }\end{array}$ & $\begin{array}{c}\text { Reception of } \\
\text { visitors }\end{array}$ & Promotion & $\begin{array}{c}\text { Control \& } \\
\text { Management }\end{array}$ \\
\hline $\begin{array}{l}\text { Completely under the } \\
\text { direction of the } \\
\text { authorities }\end{array}$ & 53.3 & 74.5 & 42.1 & 32.4 & 73.2 & 72.6 \\
\hline $\begin{array}{l}\text { Be notified by the } \\
\text { regulator about rural } \\
\text { tourism development } \\
\text { activities after the } \\
\text { contents are completed }\end{array}$ & 55.7 & 73.6 & 43.8 & 33.6 & 74.7 & 74.5 \\
\hline $\begin{array}{l}\text { Participate in } \\
\text { consulting about rural } \\
\text { tourism development } \\
\text { content for managers }\end{array}$ & 74.2 & 12.5 & 82.4 & 74.3 & 45.3 & 35.1 \\
\hline
\end{tabular}




\begin{tabular}{|l|c|c|c|c|c|c|}
\hline $\begin{array}{l}\text { Participate in } \\
\text { providing information } \\
\text { to the survey staff } \\
\text { according to the } \\
\text { survey available }\end{array}$ & 74.5 & 54.4 & 83.5 & 73.4 & 44.8 & 54.6 \\
\hline $\begin{array}{l}\text { Participate in } \\
\text { proposing rural } \\
\text { tourism development } \\
\text { policies for managers }\end{array}$ & 72.4 & 40.7 & 82.7 & 75.8 & 42.1 & 56.8 \\
\hline $\begin{array}{l}\text { Contribute material } \\
\text { and human resources } \\
\text { to rural tourism }\end{array}$ & 0 & 45.8 & 62.9 & 62.1 & 41.9 & 22.4 \\
\hline
\end{tabular}

(Source: Results of survey data analysis, 2020)

\section{Analysis of factors affecting the participation of people in rural tourism development in Bac Kan province}

Table 8. Regression analysis of factors affecting people's participation in rural tourism development

\begin{tabular}{|c|c|c|c|c|c|c|c|}
\hline \multirow{2}{*}{ Model } & \multicolumn{2}{|c|}{$\begin{array}{c}\text { Unstandardized } \\
\text { Coefficients }\end{array}$} & \begin{tabular}{|c|} 
Standardized \\
Coefficients
\end{tabular} & \multirow[b]{2}{*}{$\mathbf{t}$} & \multirow{2}{*}{ Sig. } & \multicolumn{2}{|c|}{ Collinearity Statistics } \\
\hline & B & Beta & Beta & & & Tolerance & VIF \\
\hline (Constant) & 2.316 & .215 & & 10.786 & .000 & & \\
\hline LI & .400 & .031 & .481 & 12.951 & .000 & .973 & 1.028 \\
\hline $\mathrm{RC}$ & -.176 & .033 & -.199 & -5.385 & .000 & .982 & 1.019 \\
\hline QD & .120 & .032 & .142 & 3.728 & .000 & .925 & 1.082 \\
\hline $\mathrm{CS}$ & .106 & .031 & .129 & 3.372 & .001 & .919 & 1.088 \\
\hline
\end{tabular}

Source: Results of survey data analysis, 2020.

According to the multivariate regression results table, it appears that there are 4 factors that have a linear relationship with the participation of people in rural tourism development with a significant level. $<5 \%$ ( $\mathrm{P}$ - value $<0.005)$ includes the benefits, barriers, views and policies of the State. This means that we have a basis to reject the hypothesis $\mathrm{H} 0$ that there is no linear relationship between Benefit (hypothesis 1), Barrier (hypothesis 2), Viewpoint (hypothesis 3) and State policies (hypothesis 4) with the participation of people in rural tourism development. Therefore we accept H1 (alternative hypothesis) - there is a positive relationship between these factors with people's participation in rural tourism development.

Considering the standardized Beta values, we see that the variables of interests, views and policies of the State are all greater than 0, which means that the variables have a positive influence on participation in tourism development. In rural areas, the barrier variable has a negative impact on participation in rural tourism development in Bac Kan province.

\section{Conclusion}

The study comes to some conclusions and suggests policies to increase the participation of people in rural tourism development based on the analysis of the situation and the model of factors affecting participation of people in rural tourism development in Bac Kan province, as follows: 
Increase the benefits of rural tourism

It is necessary to have initial support for newcomers in tourism, such as: investment consulting, consulting on production and business techniques, organizing training courses to help them acquire the necessary skills and knowledge to provide the best CBT products

Local authorities need to involve farmers in their research in order to add new value with their own "rural" resources to develop services.

It is necessary to clearly identify the goal of tourism in rural areas that is to develop ecotourism and cultural tourism by diversifying participants. Efficient exploitation of resources for tourism development needs to pay attention and share benefits with local communities, ensuring sustainable development.

\section{Limit barriers in rural tourism development}

Information on tourism development planning, plans and policies should be transparently publicized, so that communities in the region can actively participate. It is necessary to consider the main factors for rural tourism development, which includes community factors and building up the traditional cultural identity of each ethnic group, each locality; participation of rural communities and people, as subjects of rural tourism; promote the role of other stakeholders.

The authorities at all levels, especially the grassroots level, need to organize forums for people to contribute with their opinions to tourism development plans and tourism plans in the area. Through the participation of local communities at developing traditional industries and festivals, tourists can visit and experience rural communities.

Travelling agencies together with local authorities should recommend to the superior authorities to remove barriers to rural tourism development such as quality of local tourism human resources, people's knowledge and experience, and people working in tourism.

\section{Raising people's awareness about rural tourism}

o Visit each household, talk and listen to people's opinion. This is a basic method to create opportunities for conversation, openness and intimacy, thereby confirming people's desire to participate in tourism, listening to their comments and assessments.

o Group discussion: group discussions are conducted according to local units or industry groups. Group discussion is a meeting with a large number of participants, according to specified topics. Through group discussion, it is possible to see the major opinion of the people in the area on relevant issues, thereby building overall measures to impact groups of people in the region.

o Organize training programs for people: training sessions may or may not be tourism related. Topics may be related to agriculture and new rural construction incorporating tourism development. In addition, training programs can also be designed to raise people's awareness by combining educational, propaganda and economic methods.

\section{Complete State policies to support rural tourism development}

The State needs to improve tourism planning for each locality and strengthen state management to implement approved plans. For localities that already have a clear potential for rural tourism development, priority must be given to developing infrastructure, supporting facilities to attract more tourists;

To improve mechanisms and policies to manage tourism services, there should be special courses for local government officials to raise awareness about tourism development. Continue to improve the management mechanism, simplify administrative procedures, and create an open environment to attract investment in tourism development 
To build a mechanism to attract capital from the people to invest in tourism development; implement the socialization of the conservation and embellishment of monuments, landscapes, festivals, folklore activities, craft villages for tourism development. Perfecting tourism development mechanisms and policies in order to create the most favorable conditions for residential communities to participate in tourism activities.

To develop mechanisms to attract capital from the people to invest in tourism development, to socialize the conservation and embellishment of monuments, landscapes, festivals, folklore activities, and villages.

To step up the training of human resources for tourism enterprises, to introduce rural tourism development training programs to training establishments.

Strengthen market expansion and propaganda for rural tourism programs built on the basis of ensuring the relationship between exploitation and sustainable development of natural resources

\section{References}

1. An, W. and Alarcon, S. (2020). How Can Rural Tourism Be Sustainable? A Systematic Review, Sustainability 2020, 12.

2. Bac Kan Statistical Office (2020). Statistical Yearbook of Bac Kan in 2019.

3. Cengiz, T. et al. (2011). Participation of the local community in the tourism development of Imbros (Gokceada), African Journal of Agriculture Research, 6 (16), pp. 3832-3840.

4. Ertuna, B. and Kirbas, G. (2012). Local community involvement in rural tourism development: The case of Kastamonu, Turkey, Special Issues, 10(2).

5. Huy, D. T.N. (2012). Estimating Beta of Viet Nam listed construction companies groups during the crisis, Journal of Integration and Development, 15(1).

6. Huy, D. T.N., Loan, B. T. and Anh, P. T. (2020). Impact of selected factors on stock price: a case study of Vietcombank in Vietnam, Entrepreneurship and Sustainability Issues, vol.7, no.4, pp. 2715-2730. https://doi.org/10.9770/jesi.2020.7.4(10)

7. Huy, D. T.N., Dat, P. M. and và Anh, P. T. (2020). Building and econometric model of selected factors' impact on stock price: a case study, Journal of Security and Sustainability Issues, vol.9(M), pp. 77-93. https://doi.org/10.9770/jssi.2020.9.M(7)

8. Huy, D.T.N., Nhan V.K., Bich N.T.N., Hong N.T.P., Chung N.T. and Huy P.Q. (2021). Impacts of Internal and External Macroeconomic Factors on Firm Stock Price in an Expansion Econometric model-A Case in Vietnam Real Estate Industry, Data Science for Financial Econometrics-Studies in Computational Intelligence, vol.898, Springer. http://doi-org443.webvpn.fjmu.edu.cn/10.1007/978-3-030-48853-6 14

9. Kumar, S., and Sekhar. (2020). Technology and innovation: Changing concept of rural tourism - A systematic review, Open Geosciences, 12(1).

10. Látková, P. and Vogt, C. A. (2012). Residents'attitudes toward existing and future tourism development in rural communities, Journal of Travel Research, 51(1), pp. 50-67.

11. Ministry of Culture, Sports and Tourism (2013). Practical manual for rural tourism development in Vietnam, Ha Noi.

12. Nguyen, D. T. and Nguyen, T. M. T. (2009). Scientific research in business administration, Thong ke publishing company, Ha Noi.

13. Nguyen, T. M. H. (2016). Participation of local communities in mountainous tourism development: A case study in Sapa, Lao Cai, PhD Thesis, National University of Economics, Ha Noi.

14. Nguyen, X. Q. (2016). Research on community participation in rural transport infrastructure development in Dong Nai province, PhD Thesis, Vietnam Academy of Agriculture, Ha Noi. 